\title{
JUSTICE A YEARNING IN THE IMPLEMENTATION OF THE CONTRACT IN THE SOCIETY
}

\author{
Siti Malikhatun Badriyah \\ Faculty of Law, Diponegoro University, Indonesia \\ malikha_b@yahoo.com
}

\begin{abstract}
The contract is very important in the life of society in the activities of economy, especially since the Foundation in various business activities. The contract is based on the agreement that creates a legal relationship between debtor and creditor. On the other hand often arise out of various problems in the contract, especially concerning the imbalance of legal relationship between the parties. The existence of an imbalance that ultimately gives rise to injustice. Even to this day still be a yearning for Justice, has not realized in various implementation contract in Indonesia.
\end{abstract}

Keywords: contract, justice, yearning, balance, legal relationship

\section{Introduction}

The contract is not something alien in society life, especially in the business world. Any legal relationship conducted by businessmen in running various businesses are always based on the contract. The contract provides a variety of benefits for the life of the society, because of the contract shall rise to engagement for the parties to realize the goal of contract. On the other hand, the contract many problematic, because often there is an imbalance of legal relationship between the parties, which boils down to the injustices that arise in the life of the society. [1] Fairness of contracts still to be something the yearning of the community, has not realized.

The imbalance of legal relationship between the parties that could potentially give rise to numerous conflicts in the life of society, which would disturb the balance in order of society. Therefore efforts embody values of fairness- 
based contract that is becoming very urgent to be always carried out by various parties, both legislator, government, business, and society.

Justice is one of the main factors in addition to the factor of certainty and expediency that must exist in the rule of law, including the law of contract. These three values there should be proportionately, but nevertheless is often conflict between one with another (spannungsverhaltnis). If so, then a justice should take precedence without neglecting the other two elements, namely, legal certainty and expediency.

\section{Research Methods}

Research Methods in this paper is a mixed method, qualitative and quantitative. Face to face interviews (instrument: questionnaire and in-depth interview). Key Person: Notarial, Judge, Lawyer, Businessman. Tools of analysis are Legal Pluralism, which integrates philosophical, normative approach, sociological approach. The validity triangulation based on in-depth interview as qualitative tools.

\section{Discussion}

\section{a. The Standard Contract Development in the Society}

Paul Bohanan and Paul Vinogradoff ${ }^{[2]}$ suggests that the law grew out of practices or customs that occur in society. Law is institutionalization back over the customs in the society (reinstitutionalization). Human life is dynamic. Society structures constantly change along with the development of society. Changes in society structure impact on the life of law in the society. ${ }^{[3]}$

The law is the protection of the interests of a human being or society. Society is always evolving, then any human interests expanded macro as well as micro. The law is dynamic (historsisch bestimnt), always follow the development ${ }^{[4]}$. The development of the law looking for ideally namely accomplishing the three basic ideas of law, i.e. legal certainty (rechtssicherkeit), 
expediency (zweckmassigkeit), and justice (gerechtigkeit) ${ }^{[5]}$. Gustav Radbruch [6] call it as the underpinning of the ideals of the law (idee des Rechts). The ideals of this law would guide people. The third of these basic values must be present in a balanced way, but often not always harmonious but opposed (spannungsverhaltnis). In the case of contradiction going on, that should take precedence is justice.

Legal changes as a result of the dynamics of change in society are also happening in the legal contract. According to Sir Henry Maine ${ }^{[7]}$ law developed from status to contract). This is in accordance with the development of society from the simple community (primitive) and homogenized into a complex community order and heterogeneous in nature. Maine argued that at first, a person's legal action is determined by the position/status. In modern society, the relationship between members of the society is conducted on the basis of a system of rights and obligations contained in the form of the contract which is made consciously and voluntarily by the parties. Sir Henry Maine ${ }^{[8]}$ did not rule out the role of legislation and codification in the development of the law in the community who has advanced. Maine distinguished presence of static and progressive society. A progressive society that is able to develop the law through three ways: "fiction, equity, and legislation. Furthermore, for Maine, Volgeist is not something mystical, because according to Maine, on the way of life of the community there is the development of a situation which is determined by the status to the use of contract/agreement. Sir Henry Maine is included in the Historical Madzab, but his thinking is different to Friedrich Carl Von Savigny. According to Savigny legal system is a reflection of the soul of the people who developed the law. All law comes from the Customs and beliefs and not derived from a founding act. According to Von Savigny and some of his followers can be concluded that the law was found, not made. Background the Savigny opinion arising from the conviction that the world is made up of an assortment of people have volgeist (the soul of the people) of different looks from cultural differences. ${ }^{[9]}$ 
At present, the development of the law of treaties was from contract to status. This can be seen from the fact the more development of the standard contract. The standard contract is made by one of the parties generally have a strong bargaining position. The other party, which in general are at a disadvantage living approve or reject the contract (take it or leave it). In practice, contracts of this kind are often imbalanced, leading to injustice for the weak.

The development of the contract, also appears in the development of the definition of the agreement. Article 1313 Civil Code states that the Treaty is the Act by which one or more persons committing himself to one or more other persons. The definition of agreements listed in Article 1313 Civil Code, unclear and incomplete. Therefore sought the definition of the doctrine. General view of this agreement is considered an act of law. Sudikno Mertokusumo, Van Dunne did not agree with that view. The nature of the agreement that there is momentum, i.e. the stage of pre contractual, contractual, and post contractual. Offer and acceptance occur at the stage of pre contractual, which only represents one of the phases in the agreement. Whereas the agreement includes the third stage. At the stage of pre contractual there are two legal deeds, i.e. an offer and acceptance are inter-related to each other to inflict meeting of mind. Thus the agreement is not a legal action but the legal relationship. $\stackrel{[10]-S u d i k n o}{ }$ Mertokusumo ${ }^{[11]}$ Siti Malikhatun Badriyah ${ }^{[12]}$ argued that the agreement is a legal relationship between two or more parties based on the agreed to give rise to legal consequences. Legal consequences in the form of the rights and obligations that may be imposed by the enactment of the law.

In Black's Law Dictionary contract as an agreement between two or more parties creating obligations that are enforceable or otherwise recognizable at law. Menurut Treitel $^{1}$ contract as an agreement giving rise to obligations which is enforced or recognized by law. The factor which distinguishes contractual from

${ }^{1}$ Treitel in Paul Richards, Law of Contract (London: Pitman Publishing, 1993), p. 10 
other legal obligations is that they are based on the agreement of the contracting parties.

Currently in its development, in General, the agreement is made in written form, because it can provide more legal certainty and to facilitate in the proof in case of later disputes, there is even a tendency to make the agreement in the form of standard (standaard contract/contract unconscious) ${ }^{[14]}$. Standard contract grows and grow almost in all facets of life, especially in the field of economy. ${ }^{[15]}$

According to Sudikno Mertokusumo ${ }^{[4]}$ standard contract is an agreement that its contents are determined a priori by the parties which make up, so adherent party does not feel free to his will because there is no meeting of mind and felt on the weak. In this case, the other party only take or leave the agreement, without being able to increase or decrease the content of the agreement.

The characteristics of standard contract according to Mariam Darus Badrulzaman ${ }^{[17]}$ is as follows:

1) The contents are set unilaterally by the party position (its economy);

2) The society (the debtor) is not at all join together to determine the contents of the agreement;

3) Compelled by necessity the debtor is forced to accept the Covenant;

4) Certain forms of (written);

5) Prepared in bulk and collective

The background of the growing standard contract was due to socioeconomic circumstances. The agreement has the force of law upon standard habits prevailing in the society and trades. In daily life widely used standard contract because of badly needed by society, especially in making a complicated agreement so it takes a lot of costs, time and effort to organize them.

Compare with Remy sjahdeini ${ }^{[18]}$ which States that the standard contract is an agreement that is almost the entire clause that was standardized by the user and the other party essentially had no opportunity to negotiate or ask for changes. A 
standardized form is not that agreement but the clause. With reference to Article 1338 (3) of the civil code, although a contract was drawn up in standard by one party, but the agreement should be implemented in good faith. [19] The implementation of the contract in good faith means that the contract must be carried out according to the terms Redelijkheid and billijkheid (reasonableness and fairness). Redelijk means understandable intellect, with common sense, with gratitude. Billijk means that can be perceived as gentlemanly, as worthy and just. Here is not the intellect but feelings are important. Therefore the behavior of the parties on the implementation of the contract should be tested on the basis of objective norms are unwritten. ${ }^{[201}$ As a consequence these provisions, then all contracts, including those created in the form of a standard should always consider the appropriateness and propriety. As expressed above, that the contract will give rise to legal consequences for the parties, namely the existence of a legal relationship between the parties which made the agreement. This legal relationship is reflected in the rights and obligations provided by law. ${ }^{[21]}$

In fact, the agreement raises the engagement between the parties so that the contract is one of the sources of the engagement. ${ }^{[22]}$ the engagement is a legal relationship between certain people between the creditor and the debtor. [23] the $\mathrm{Gr}$. Van der Burg ${ }^{[24]}$ suggests that legal relationship between the two parties in this engagement is a legal relationship between two or more parties in the field of the law of property in which on the one hand there are the rights of the other party and on any obligation. The definition of rights and obligations in this regard is to Excel. [25]

\section{b. Justice in the contract as a Yearning in people's lives}

There are various definitions of fairness according to various authors, among others, John Locke, Rousseau, Immanuel Kant, and John Rawls who renders justice in the contract. These thinkers realized that without a contract and the rights and obligations thereof, then the business society will not run. Therefore 
in the absence of a contract, people will not be willing to be tied to and dependent on the other party's statement. The contract provides a way of ensuring that each individual will fulfill his promise, and this allows the occurrence of transactions between them.

John Locke, Rousseau, and Immanuel Kant, although theory-based contract, but his justice by John Rawls was criticized because it tends to be of utilitarianism and intuitionism. John Rawls suggested that the principles of Justice for the basic structure of society is the objective of the agreement. ${ }^{[26]}$ Rawls respect of the principle of Justice as fairness, in this case the default equality position with regards to natural conditions in the traditional theory of the social contract. Rawls explains regarding the two principles of Justice, namely: first, everyone has the same rights to freedom of the basis of the most extensive, covering the same freedom for all people; Second, the social and economic inequalities must be arranged in such a way that (a) can be expected to benefit all people, and (b) all the positions and offices held open for everyone. The term of difference sosiàleconomical principle difference led to the dissimilarity in the prospect of a staple item to get welfare, revenue, and authority. ${ }^{[27]}$ Of the second principle, showed them the most less has a chance to reach the prospect of prosperity, income and authority should be given special protection, so as to provide an advantage that is reciprocity (reciprocal benefits) for everyone, both originating from a group of lucky or unlucky. ${ }^{[28]}$

Value ${ }^{[29]}$ of justice shared basic values of Pancasila is one of the other values that serve the purpose of a value system. To Indonesian people, Pancasila values placed as basic values. Pancasila has the basic values that are universal and fixed. The values were arranged in hierarchical and pyramidal. The substance of Pancasila with the five basic in divinity, humanity, unity, populist and social justice are system of values. The basic principle of containing certain quality it is the ideals and expectations or anything that will be reached by the Nations of Indonesia which will be transformed into a concrete reality in both the areas of life 
of society and State. ${ }^{[30]}$ According to Daniel j. Muller ${ }^{[31]}$ the value of a thing is very determined the results of interaction between a subject and an object that rate is assessed. Invalid constructs a value did not get consensus on the definition is due to invalid constructs the value of the more abstract and storied higher than on attitude and therefore more difficult to clearly concepted. Max Scheler ${ }^{[32]}$ Notonagoro, ${ }^{[33]}$ suggests that the existing values are not the same noble and not the same height. According to Driyarkara ${ }^{[34]}$ value is divided into three kinds, namely: (1) the value of the material (for physical human being); (2) the vital Value (for activity: health); and spiritual values which consists of four levels: the first value of truth, the second value of the three values of beauty, goodness and the fourth is a religious value. When are reviewed from the basic values of Pancasila stratification, social justice is the top rated pyramid of Pancasila value system. According to Notonagoro Pancasila values, including the value of spirituality, but the spiritual values that recognize the value of the materials and the vital value. The value of the first sila of the Pancasila as its base and social justice as its objectives. ${ }^{[35]}$

Justice has a variety of meanings and the significance of diversity has led to diversities. Actually, in the tradition of the social sciences, there have been many reflections on the meaning of social justice. According to Mubyarto, [36] Muhammad Suud ${ }^{[37]}$ social justice have a relationship very closely with social welfare. In the Constitution, social welfare is regulated in article 33 and 34. It can be said that the social welfare regarding the fulfillment of the objective needs that must be set in the organization and economic system based on kinship. Social welfare is a means of material that must be met to achieve the sense of security and peace in the so-called social justice, while social justice is a higher purpose than simply a prosperity. The founding fathers of Indonesian country base their ideas and their ideals on the idea that universal said. However there are still many people interpret social justice distributive justice simply, though, there is a difference between pretty basic social justice with distributive justice. If distributive justice more interpreted as property distribution of the ' justice ' of people to the 
individual or group, social justice in a broader sense, is a State that allows each of the individuals and groups in society can flourish. In the distributive justice the pressure on individuals is dominant, while in social justice to pressure the individual was placed in the social or its dimensions. A major problem is the classification of social justice (distribution) and loads of the people by Brian Barry summarised in three groups: (1) economic (money); (2) political (power); and social (status). ${ }^{[38]}$ Marxism looked at not from the aspect of distribution justice but from the aspect of the production. Distribution can still be arranged and fixed (progressive fiscal, for example), but as long as the production is in the hands of capitalists, during this time there is a problem with justice. ${ }^{[39]}$

About this justice Abu Hamid Al-Ghazali ${ }^{[40]}$ combining the idea of Ancient Greece, Persia and other foreign ideas with Islamic tradition as well as trying to create a balance that is called "the middle way" in the concept of Justice. The ethical justice in the concept of Al-Ghazali was a statement of virtues of human beings, but substantially derived from justice concept. Standards of Justice that provides ethical guidance consists of four virtues that is as follows:

a. Wisdom (al-hikmah), quality of mind which determines the humans make choices. Differentiate between the good and the bad (evil) as well as curb themselves from extreme deeds under similar pressures, such as maintaining the balance between attitude blindly and outwit. The balance thus became one of the purposes of faith expressed in the principle of the "middle way".

b. Courage (Al-syaja'ah), the quality of anger and annoyance (quwwah alghadhabiyah) which can be described as a form of moral courage, not in a hurry and rash (tahawwur) and not also a coward (jubn), but a state between two extreme deed. With directed law jurisprudence) and reason, courage encourages humans to lead himself appropriately, as well as to follow the road right or the straight path (Al-shirath al-mustaqim), neglecting the street 
crime. It is also suggested to humans for some reason decided upon the heart and compassion to others.

c. Simplicity (al-' protect their), middle way that determines the quality of the human being to follow the middle road (moderate) between two extreme deeds, such as grasping and antipathy, being honest to others and moderate in the path of his life. In other words, it is a picture of "the golden path"

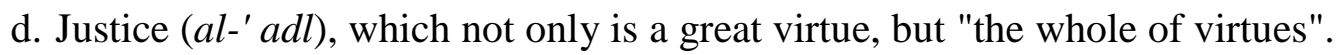
Justice is the perfection of all the virtues, which stood above equilibrium (State of balance) and a moderate stance in the behaviour of private and public affairs. Most importantly, justice is the attitude of reasonableness (insaaf) that encourages humans to traverse what is described as the path of Justice. The road to justice, according to Al-Ghazali was the right path (Alshirath al-mustaqim), based upon which humans achieve happiness in this world and the hereafter.

Justice, in this case, is the perfection of all the virtues, which stood above equilibrium (State of balance) and a moderate stance in the behavior of private and public affairs. Most importantly, justice is the attitude of reasonableness (insaaf) that encourages humans to traverse what is described as the path of Justice. The road to justice, according to Al-Ghazali was the right path (Al-shirath al-mustaqim), based upon which humans achieve happiness in this world and the hereafter.

By basing on Al-Ghazali's views on this, Esmi Warassih argues that justice should have a perfect sense because justice does not only concern the distribution of resources but must refer to a question of morals. The law should contain elements of the material as well as spiritual because realizing justice without spiritual guidance would violate the principles of humanity (example: the struggle will be the rights of a person or society in a fair manner without the guidance of divine light (Nur) can give rise to action anarchy). Justice is the nature of God because justice does not only concern human life but also the region of the 
Godhead. The application and implementation of Justice viewed from all aspects of the implementation of the earthly life as religious. ${ }^{[41]}$

The value of Justice is supposed to be a cornerstone in the contract that is practiced in the life of society so that the created contract that really can provide a balanced legal protection for both parties. Thus was created the balance of relations in society.

Although basically the contract is made on an individual basis, it still should not be contrary to the provisions of the existing normative in society (the terms of the contract: a cause legitimately halal). In Herlien's view, the parties agreement fact of interwoven with society. Because it can not be separated from the society, the New Testament can be said to be legitimate when balancing the interests of the individual with the interests of the society. The balance of the human being, even long before people are aware of its existence, the basic balance has been commonly applied. [42]

In a contract of the parties expresses the will promise in form. A fact that the contract is based on a specific goal. With the contract, then the Alliance was born. Through this contract, then the intent and purpose of the parties realized. According to Hijma ${ }^{[43]}$ goals and purpose of the contract in addition to the legal force, there is also a juridical attachment or the legal force in psychological perspective (sense-bound) and sociological (consider the community is bound).

According to P.S. Atiyah contract has three main objectives, namely: first, it is inspired by the desire to enforce promises and to protect the reasonable expectations which are generated both by promises and by other forms of conduct (impose a reasonable expectations and protect the promise that emerged from it); secondly, contract law itself is also powerfully influenced and affected by the idea that unjust's should not be 'permitted explosives (to prevent the enrichment/selfenrichment efforts undertaken unjustly or not true); thirdly, the contract law is also designed to prevent certain kinds of harm, particular harm of an economic nature, 
or at least to compensate those who suffer such harm to prevent certain kind of harm). ${ }^{[44]}$

In addition to the three main objectives as expressed by Atiyah, the author agreed with Herlien Budiono to add single purpose contract, i.e. achieve a balance of interests between the parties. This is in line expressed by Sri Redjeki Hartono ${ }^{[45]}$ that one of the laws of economics principles that it is important to note is the principle of balance of interests.

The fundamental Purpose of an agreement is derived from an appointment with function requires that in the law of contract that self-imposed. ${ }^{[46]}$ The second and third objectives confirms the terms of the mixture of society values, i.e. from justice (rechtvaardigheid) and fit (melijkheid) or glasses is our basic law is worth and deserve. In General, people made a Covenant with the other person is to their own interests. Purpose or primary function of exchanges through the contract was allowing developing viable economic structures in the society, i.e. by forming a system of benchmarks and the balance of interests in which it is possible to smooth consumption, production, and the creation of an income for the whole society. Furthermore, it can also add that motivation or background of the deeds of a person with intent to the achievement of specific objectives, on the one hand, the influence of the market economy as well as its own interests, while on the other hand is also influenced by the ethical considerations and morals. The fourth goal is to achieve a balance; merit or particular social attitudes----inner conditions here that reflect a sense of gratitude or satisfaction---and effort consciously reaching for the opportunity the existence of immaterial (immateriele zijnmogelijkheid), as it is said Soepomo ${ }^{[47]}$ that the law expects of the parties, the ability to be keeping social propriety, whether one party against the other as well as against all persons who may be involved in a transaction.

With the balance of contract in the whole process of either pre contractual, contractual, post contractual, i.e. results obtained will materialize the goal of the contract that gives the balance on both sides, i.e. the existence of fairness, 
expediency and legal certainty of the contract. In the agreement that gives rise to the legal relationship between the parties, should also balance the interests there, both between individuals and individuals or individuals with collective interests, namely the interest of the society to realize the country's goal as stated in the Preamble Negara Republik Indonesia 1945. In this case, be a cornerstone of Pancasila foothold for any activities undertaken by the parties to the contract activities in Indonesia, so will manifest a balance not only moral but also material dimensional religious. Thus the contract in addition to, there is legal certainty would also be beneficial to the entire Indonesian society and embody a justice.

In terms of the agreement, each party is bound to implement the achievements according to the contents of the contract in question. When these achievements are met, then the purpose of the parties to make that contract has been reached and contract the end. The implementation of the achievement (also called payment) will erase the existence of the engagement (Article 1381 of the civil code).

Fulfillment of achievement as the embodiment of the implementation of contractual obligations, other than specified by the autonomous factors (things that are determined by the parties to the contract, also defined by heteronom factor ( $\mathrm{a}$ factor outside of the parties). Force to bind a contract affected by autonomous factors or heteronom. Article 1339 of the Civil Code states that the contract binding not only to things that are expressly stated therein (autonomous factors), but also to everything that is according to the nature of the contract, required by propriety, customs, and laws (heteronom factor).

To find out the nature and extent of the rights and obligations arising from the contractual relationship, Nieuwenhuis ${ }^{[48]}$ emphasis on two main aspects, namely:

a. Interpretation (exegesis; uitleg) against the nature and extent of the contractual rights and obligations, 
b. Factors that influence on the nature and extent of the contractual rights and obligations, including:

1) autonomous factors (related to binding force of contract);

2) heteronom factors (The factors that come from outside the party), consisting of: laws, habits (gebruik), enforced by the usual terms (bestandig gebruikelijk beding), and propriety (billijkheid).

Nieuwenhuis thinking with regard to the nature and extent of rights and obligations that arise due to the legal relationship in the agreement, which emphasizes on two major aspects of interpretation as well as autonomous factors and heteronomy there is compliance with article 1339 of the civil code. From the formulation of article 1339 as mentioned above, it can be said that the parties in the legal relationship which arises because the agreement that has been made is sourced from what had been agreed upon (an autonomous factor), and other factors (heteronom factor). It can be said that the factors that determine the content of the agreement/contract are the will of the parties (the autonomous factors), as well as other factors (heteronom factor), which include: customs, laws, propriety, and justice. Both of these factors its existence must be balanced, both of which must be integrated in such a way, so that the contract made by the parties may give legal protection to the parties concerned as well as with dependencies society where the contract is made and implemented, so that any contracts made by the parties also reflect the values that exist in the society concerned. Thus the contract executed by the parties may consummate balance of the legal relationship between the parties that boils down to materialize the coveted justice in the life of the society.

\section{Conclusion}

From the explanation above conclusions to be drawn as follows.

1. The legal Relationship between the parties of the contract is always evolving in accordance with the development of the society. Initially, the contract development is from status to contract, then the next is from 
contract to status, which is visible from the more rampant the agreement made in the standard contract, which is the contract only created by one of the parties to the agreement that generally have a stronger bargaining position.

2. In the contract between the parties is often happening imbalance legal relationship between the parties, which boils down to injustice between the parties within the society. Justice has not yet been fully realized in the implementation of the contract. Justice is still a yearning in the implementation of the contract. Therefore in understanding the contract was supposed to see a variety of factors both factors will of the parties (the autonomous factors), as well as other factors (heteronom factor), which include: customs, laws, propriety, and justice. Both of these factors its existence must be balanced, both of which must be integrated in such a way, so that the contract made by the parties may give legal protection to the parties concerned as well as with dependencies society where the contract is made and implemented, so that any contract made by the parties also reflect the values that exist in the society concerned. Thus the contract between the parties can realize the balance of the legal relationships that lead to the coveted society justice.

\section{References}

[1] Siti Malikhatun Badriyah, Urgency Of Interpretation Of the Standard Contract To Achieve Justice (IOSR Journal of Humanities And Social Science/IOSR-JHSS, Volume 21, Issue 12, ver. 9, December. 2019, PP 29-36e-ISSN: 2279-0837, p-ISSN: 2279-0845, www.iosrjaurnals.org)

${ }^{[2]}$ Hanitijo Soemitro, Ronny, Social Perspective In Understanding Legal Issues, (Semarang: Great Press, 1989), p. 7.

[3] Siti Malikhatun Badriyah, discovery of the System of law in society Prismatic (Jakarta: Rays Graphic, 2016), p. 62-63

${ }^{[4]}$ Sudikno Mertokusumo, the development of the law of Treaties, the Paper of the National Seminar of Civil/Business Law Lecturer Association, Faculty of Law, Gajahmada UniversityConsortium of Knowledge Law, Yogyakarta, 12-13 March 1990, p.2.

${ }^{55}$ Sudikno Mertokusumo, Mr. a. Pitlo, chapters of the invention law, (Bandung: PT Citra Aditya Bakti, 1993) p. 3.

${ }^{[6]}$ Satjipto Rahardjo, the law in the universe in Order (Jakarta: UKI Press, 2006), p. 135. 


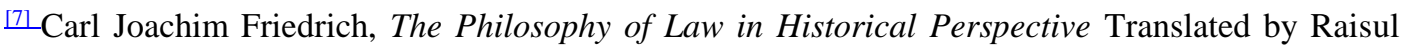
Muttaqien with the title Historical Perspective, Philosophy Of Law (Bandung: Nusa Media, 2010), p. . 177.

${ }^{[81}$ Lili Rasyidi, Philosophy of law-is that Legal? (Bandung: pt. Remaja Rosdakarya, 1991) p. . 48.

${ }^{[9]}$ Lili Rasjidi, the basics of the philosophy of law (Bandung: pt. CitraAditya Bakti, 1996), p. 70.

[10]Ibid. p . 1

${ }^{111}$ Sudikno Mertokusumo, know the law an introduction, Fourth Edition, first printing, Y ogyakarta : liberty, 1996 ) p. 10

${ }^{[12]}$ Siti Malikhatun Badriyah, re-orientation of the Franchise Agreements in an effort to Balance legal relationship Between the parties (The Journal of the legal issues, Fakulty of Law, Diponegoro University, vol. 43 No. 2, April 2014, ISSN 2151-2695) p. 204-2012

${ }^{[13]}$ Treitel in Paul Richards, the Law of Contract (London: Pitman Publishing, 1993), p. 10

${ }^{[14]}$ Saleilles in Mariam Badrulzaman Darus, A Variety Of Business Law, (Bandung: Alumni, 1994), p. . 47.

[15] Siti Malikhatun Badriyah, The Breeding of The Contract Law Principles (The Study of The Leasing Agreement In Civil Law and Common Law System), the South East Asia Journal of Contemporary Business, Economic and Law, vol. 6, Isusse 4 (Apr), ISSN 1560-2289, p. 49-54

${ }^{[16]}$ Sudikno Mertokusumo, 1990, URop.cit, p. 4.

[17] Mariam Badrulzaman Darus, Raw Agreement (Standard), its development in Indonesia, (Bandung: Alumni, 1980), p. . 4.

${ }^{[18]}$ Sutan Remy Sjahdeini, freedom of Contracts and a balanced Protection For the parties in the Covenant of Bank credit in Indonesia, ( Jakarta: Indonesia Bankers Institute, 1993), p. 66.

[19] Patrik Purwahid, the principle of good faith and Appropriateness as a basis for Revising the contents of the Agreement, (Jakarta: Elips Project, 1993), p. 3.

${ }^{[20]}$ P.L. Wery, the development of the law Of good faith in Nederland, Lustrum II notary public Specialist Courses at the Faculty of law Airlangga University, Surabaya (Jakarta, printing RI, 1990), p. . 9.

${ }^{211}$ Sudikno Mertokusumo, know the law (an introduction), Fourth Edition, first printing, 1996, p. 39.

${ }^{[22]}$ Patrik Purwahid, basics of Law Alliance, first printing, Advanced Rail, Bandung, 1994, pp. 2.

${ }^{[23]}$ See J. Satrio, A Legal Agreement, Considered Mold, (Bandung: PT Citra Aditya Bakti, 1992), p. 2.

[24] Gr. Van der Burght, books about the Alliance, in theory and Jurisprudence (Contain jurisprudence of the Netherlands after World War II), Edited by f. Tengker, (Bandung: the rail Forward, 1999)

${ }^{[25]}$ H.M.N. Purwosutjipto, the sense of a staple commercial law Indonesia 1 basic knowledge of commercial law, the four Prints, (Jakarta, ^, 1984), p. 4.

[26] John Rawls, A Theory of Justice, Translated by Sukhera Fauzan \& Heru Joon with the title A Theory Of Justice, (Yogyakarta: Pustaka Pelajar, 2006) p . 72.

${ }^{[271}$ Ibid, pp. 72.

${ }^{[281}$ Ibid p.. 73-89.

${ }^{[29]}$ Bambang Daroeso, the basis and concept of Pancasila Moral education, (Semarang: a variety of Science, 1989), p. 19.

${ }^{[301}$ Kaelan, Civics, (Yogyakarta: paradigm, 2003), p. . 70-71.

[31] Daniel j. Muller, measure the Social attitudes, Translated by Cecep Syarifuddin, (Bandung: Pasundan University, 1990), p. 5.

${ }^{[32]}$ Kaelan, Philosophy of Pancasila: the nation's view of life (Yogyakarta: paradigm, 2002), p. 124125.

[33]Notonagoro, Pancasila Scientifically Popular (Jakarta: Seven Pantjuran, 1975.

${ }^{[341}$ Driyarkara, Splash Of Philosophy (Jakarta: the national development, 1978). 
${ }^{[351}$ Darmodiharjo Darji, Santiaji Pancasila (Jakarta: , national effort, 1979).

${ }^{[36]}$ Mubyarto, Moral and Economic System of Pancasila, LP3ES, Jakarta, 1988. Pengetian more details about social welfare can be examined in Muhammad Suud, 3 the orientation of social welfare, (Jakarta: the national library, 2006), p. 1-18.

[37] Muhammad Suud, 3 the orientation of social welfare (Jakarta: the national library, 2006), p. 118.

${ }^{[381}$ Brian Barry, Theories of Justice, vol. I, (London, Harverster-Wheatssheaf, 1989), p. 146.

${ }^{[39]}$ Bur Rasuanto, social justice (Rawls and Habermas Deontologis Views), (Jakarta: Gramedia Pustaka Utama, 2005), p. . 14.

${ }^{[40]}$ Al-Ghazali in Majid Khadduri, The Islamic Conception of Justice, translated by Mochtar Zoerni \& Joko S Kahlar. with the title The Theology Of Islam Pespektif Justice (Surabaya: Treatise Gusti, 1999), p. 166-177.

${ }^{[411}$ Esmi Warassih, empowering the community in realizing the goals of the law (the process of law enforcement and Justice Issues), (Semarang: Faculty of Law, Diponegoro University, April 14, 2001), p. . 20-21.

${ }^{[421} \mathrm{http} / / \mathrm{www}$. Hukumonline.com, July 26, 2015

${ }^{[43]}$ Hijma in Herlien Budiono, Het Evenwichtsbeginsel voor het Indonesisch Contractenrecht op Indinesische Beginsel Geschoeid, translated by Partner Tristam P. Moeliono with the title The principle of balance to the law of Treaties, law of Indonesia based on Treaty principles Wigati Indonesia (Bandung, PT Citra Aditya Bakti, 2006), p. . 308.

[44]I Ibid, pp. 310.

${ }^{[45]}$ Sri Redjeki Hartono, Indonesia, Economic Law (Poor: Bayumedia Publishing, 2007), p. 62-63.

${ }^{[46]}$ P.S. Atiyah in Herlien Budiono, loc. cit.

${ }^{[471}$ Herlien Budiono, Ibid, p . 311.

${ }^{[48]}$ Nieuwenhuis in Agus Yudha Hernoko, Op. cit., p. 20 